Journal of Law \& Social Studies (JLSS)

Volume 3, Issue 2, pp 79-86

www.advancelrf.org

\title{
Evidential representation of using the modern devices and decision- making feasibility in Pakistan
}

\author{
Muhammad Arif Saeed (Corresponding Author) \\ Lecturer, Department of Law, \\ The Islamia University of Bahawalpur, Pakistan \\ Email: arif.saeed@iub.edu.pk \\ Aftab Hussain Gillani \\ Dean, Faculty of Law, \\ The Islamia University of Bahawalpur, Pakistan \\ Email: draftab90@gmail.com
}

\begin{abstract}
In the long run of modernity and technicality, the use of smart appliances in every field of life has been the need and demand of the era. The evidential representation by using modern devices is permissible in various developed judiciary cultures of the world. Pakistani courts and the judiciary system are also adopting modern devices to present the evidence in the courts for authentic decision-making. The articles and sections of Qanun-e-Shahadat order, 1984 and Electronic Certification Accreditation Council under Section 18 clarified using modern technologies to present the evidence in the courts with state and religion's perspectives of acceptability. The study descriptively demonstrated various types of modern devices use for evidential representation of offenders data; press reports and press clips, fax, email and internet evidence, cell phones, computer-related data, audio recordings, photographs and screenshots, video films and video cassettes, CCTV footage, polygraphy test and DNA test. In each type of modern evidential representation, the registered, recorded and solved cases have also been mentioned as proof of modern devices application in court decision-making feasibility. The study found that the unapproached low-class sector of society feels reluctant to rely on and use modern devices for court hearings and decision-making due to unawareness and unavailability of modern resources. There is also the issue of some insecurities and inadequacies of using modern devices as evidential representation because of editing, cropping and regenerating the duplicate evidence that could not be verified due to lack of technical flaws and advancement of computerized technology.
\end{abstract}

Keywords: Evidence, modern devices, decision-making, Pakistani courts

\section{Introduction}

History of start using modern devices in court proceedings

Internationally, various countries started using electric devices as a mode of presenting evidence in court proceedings. The ESIGN Act section 106 and another international Act named UETA section 2 defined an electric record as the contract or other records generated, created, delivered, communicated, received, and saved by electronic means. The electric evidence was defined as any latent probative value that is wrought, created through, saved, or communicated by any electric device, plays a significant role in criminal tracing procedure.

As the American Civil War started in 1891, morse codes were used to send electric messages by telegraphy. These messages were considered as agreements to the terms and intended as enforceable telegraphic messages. The first registered case of enforceability of these electric telegraphic messages was from New Hampshire Supreme Court case in 1869 (Singleton, 1999). Moving forward, in the 1980s, some individuals and many companies started using fax machines as a mode of communication for fast delivery and high priority of document confidentiality. The image of the signature and transmission was electric and imprinting of the original signature was on paper and original 
document. Various courts in different jurisdictions have implicated the enforceable electric signatures as agreement and proof of communication to resolve any relevant case.

Moreover, the agreement was made through email, entering the electronic signature for ATM and entering a PIN (Personal Identification Number) into the bank or signing any electronic document with a digital pen online. These modes were recorded as evidence in favor or against the person in resolving the case. The first agreement was signed electronically by two sovereign nations to promote electronic commerce included the United States and Ireland (1998) (Gabrial, 2000).

\section{Modern devices usage in Pakistani courts}

The zenith courts of Pakistan also acknowledge the implacability of the scientific evidence that the judgments and practices exhibit in the same manner. In the registered legalized website of updating resolved cases in Pakistan from all types of courts, 17 cases were found to use the words "modern devices" and modern evidence" to resolve the cases. The judiciary system accepts that some cases cannot be handled without proper evidence and the assistance of experts. Under Article 59 of Qanun-e-Shahadat order 1984, globally accepted devices are also permitted to use in Pakistan as modern evidence. By implication, modern devices as evidence, the case law reported in PLD 2010 FSC 215 reproduced the statement that Holy Quran and Sunnah did not forbid employing the scientific and analytical methods to discover the truth. Instead, the Holy Quran strongly recommends discovering and investigate the truth. Courts enforce the reception of advanced evidence in the matters related to the offense of Zina (enforcement of Hadood) ordinance 1979, including DNA test is recommended.

The Pakistani judiciary system is concerned about tempering such evidence and devices because of advanced technologies and cybercrimes. There is the need to be conscious about the mimicry of the evidence while accepting the audio or visual proof because of photoshop techniques. The recent case (PLD 2016 LHR 570) highlighted crossexamining the provided electronic evidence once presented in front of the court to verify the proof's authenticity rather than accept it as globally implement.

\section{Qanun-E-Shahadat order 1984 and modern devices}

In the Pakistani scenario, the legal regime acknowledges the admissibility of modern and technical evidence, especially in articles 59 and 164 of Qanun-e-Shahadat order, 1984. A registered solved case, ref.\# 2019 PCRLJ 57 Gilgit-Baltistan Chief court (Shoaib Ahmad Vs. State) also admit the modern devices evidence under article 164 of Qanun-e-Shahadat, in which crime detected in CCTV footage and accused was arrested. Another case ref\# 2017 PLD 698 Lahore High Court Lahore was resolved that relate to dissolution of marriage in which video recording was presented in front of the court as modern evidence to show the torture of the husband on wife. While article 164 of Qanun-e-Shahadat 1984 was not strictly applicable in the family court, the family court found it not to be bare to receive such evidence. So, the modern devices' evidence is also considered in the family court after the verification and inquiry procedure. Case ref.\# 2017 PCRIJN 125 Lahore High Court Lahore also resolved the issue of rash driving and neglecting the traffic signals. The evidence was attained in the shape of modern means.

The collection of evidence using the modern mechanism has become increasingly old-fashioned with the introduction of modern technology; the new generation of legal frat tracked the latest technology, which the modern world has used with tremendous follow up. The majority of the opinions present that the evidential representation is valuable and helpful while using modern technology. Before the legalization of Qanun-e-Shahadat order 1984, the implication of modern and technological devices for the evidential representation was not in action and practice to explore the truth for reaching the conclusive remarks of any case. Some new articles were added to the Qanun-eShahadat order, 1984 to meet the global challenges associated with foreign litigation. The action was taken to advance the inappropriate dimension strategy for discovering the actual scenario. The Code of Civil procedure also coordinated with the Qanun-e-Shahadat order, 1984, for recourse the Courts trails and investigational steps conducted under the Law Enforcing Agencies. Resultantly, article 164 was added in Qanun-e-Shahadat order, 1984 with the following mentions:

"Construction of evidence that has become accessible due to the use of modern devices; the court may allow producing any available evidence because of modern devices and technology if consider appropriate."

The emphasis of the enactment axes around the usage of terminologies "Modern devices and Techniques."

In the prolongation of the enactment as mentioned above of Qanun-e-Shahadat order, 1984, the procedure of implementation of these articles in the litigant public of the country and foreign countries was inserted in the Code of Civil procedure vide order V, rule 20(b) with the amendments in 1994 as: 
"Any electric communication device may include telex, fax, radio, television, telegram and phonogram."

Most commonly, the execution of the modern services was efficiently carried out, but the legislative and procedural hurdles were found in its implications as the services and the communication was made through electric means. These modes of communication were hard and insufficient to believe in the court procedure because of unsigned and un-attested makers' issues creating the uncertainties of execution. Despite the uncertainty of the un-signed proof of the makers through the electronic devices according to Electronic Transactions Ordinance, some legal obstructions were filled up in harmoniousness with that law, vide enforcement of 2002, the Electric Transactions Ordinance has become the part of Qanun-e-Shahadat order, 1984 under the enactment of Article 2(e) as mentioned here:

"The expression of 'electronic information system,' 'automated,' 'electric documents,' 'electronic signs,' 'advanced electric signatures' and 'security processes,' shall be considered the meaning assigned under the Electronic Transactions Ordinance, 2002".

After this act enactment, the communication and implication through the electronic modes irrespective of being un-signed were held by the courts duly executed from all the pertinent allegations.

The current study has been designed to check the admissibility of modern devices as an evidential provision platform to facilitate the judiciary's decision-making of criminal cases. The study will be significant for the lawmakers and judicial officers to know the flaws and needs to generate the laws about the implication and improvements of some laws to strengthen the judicial procedure and case hearings in more technological and modern ways rather than follow the typical ways of evidence representation and acceptance.

\section{Literature review}

The literature found that laws related to the use of electronic devices as evidence lack advancement with modern development in the legal acts in other countries. Moreover, Pakistan's primitive source of evidential law is Qanun-e-Shahadat Order, 1984, based on the primitive Evidence Act 1872. This act was the British Empire's legislation in the Indo-Pak subcontinent that does not carry fundamental rules of Sharia regarding evidence and testimony (Abbasi, Rafique \& Badshah, 2021). Modern devices are electronically active, and these devices in the shape of evidence are not like physical evidence. Such evidence needs more authentication, which is not required else. Digital forensics is necessary to foolproof the provided evidence in court and need more precautions to deal with it (Abbasi \& Iqbal, 2020). A study also demonstrated that modern devices generated cybercrime. The establishment of the National Response Centre for cybercrime under the control of the Federal Investigation Agency (FIA) putting their best efforts to stop misusing the internet and presenting the modern evidence in courts for cases resolving. The department is working for the capacity building of law enforcement agencies and dealing with the expertise of information system security audit, digital forensics, penetrating testing/training and technical investigation (Usman, 2017). Furthermore, the misuse of modern technologies is creating more crimes and more modern evidence as a result of illiteracy counts more for indulgence in crime, especially in rural areas among women (Zakar, Zakar, Qureshi \& Fisher, 2014).

\section{Research methodology}

It was a descriptive qualitative study that used the secondary data of Pakistan's registered and authenticated website related to the record of resolved cases, updates about new laws and article amendments, along with the journal articles about judiciary proceedings and case studies. The site name is "Pakistan Law Site" link Pakistan Law Site and some legal digest of Pakistan including PLD, SCRM, YLR, CLC and PCRLJ. There is the description of the mode/type of evidence or devices used to represent evidence in courts. These modern modes include press reports and press clips, fax, email and internet evidence, cell phones, computer-related data, audio recordings, photographs and screenshots, video films and video cassettes, CCTV footage, polygraphy test and DNA test. Each type of modern device has been mentioned with the detailed use and resolved cases in the history of Pakistan along with the implication of the relevant laws, ordinances, sections, and Articles of various law orders.

\section{Results}




\section{Types of Modern devices as evidential representation in Pakistani judiciary}

After the amendment and enactment of multiple articles of Qanun-e-Shahadat 1984 in Pakistan, modern devices evidence took a considerable space for presentation in court proceedings. In Pakistan, various modern devices are used to represent the facts in actuality, elaborated as follows along with the references of the resolved cases under the type of modern device.

\section{Press report and press clips}

In the Pakistani judiciary system, according to the supreme court of the state (2021 SCRM 873), a press report is admissible when the reporter generates it for others, not for his interest and purpose. It could be the proof of the contents that can be proved unsafe for criminal justice administration. A case of property attorney (2021 PLD 715) was resolved by the initial report of the property claim and sale when the wife of a late husband registered her case of property ownership. The court did not satisfy the lady's claim, and the case was dismissed while not handing over the claimed property to the lady. This is how the new report helped to resolve the case. Another case (2021 YLR 1410) demonstrated the murder case in a press report used in the court as evidence. The court re-verified the report, and the statement of the witness was re-recorded for this purpose. The court appreciated the evidence, and the case was resolved by grasping the murderer. A very significant case (2021 PLD 1) was reported as an opponent of the president because of the pending case. The president publicized the report through the media for public information. This report proved the president innocent for being straightforward and clear from his side.

\section{2. $\quad$ Fax}

The use of fax as the evidence in courts for the judicial procedure has been helpful for the case resolution. A case (2019 PLD 602) was registered about the dispute of construction of recreational club on the land belongs to Railway property. The railway administration first did not show any objection in the sent fax to the responsible respondent. Later, it became a matter of dispute. The court found that sending private fax to the respondent in the private communication was a foul in bidding. There should be a declaration of rules and regulations constructed by the railway administration in the public advertisement. So, the case closed in favor of the petitioner. The other case (2019 PLD 11) found the plaint rejection of sale and purchase and recovery of the amount. There was the confused contract statement that was found in the evidential shape of email and fax. The record of the faxes sent by the defendant was later declared contradictory about the place of delivery. So, the agreement and contract were canceled to recover the invested amount in the court.

\section{Email and internet evidence}

The admissibility of verified emails and internet connections proved to be used and valuable in resolving criminal cases in Pakistani courts. There is a record of a case related to terrorism (2021 SCRM 873) resolved by the implication of the Anti-Terrorism Act (XXVII of 1997) Ss. 302(b), 120-A, $362 \&$ 365-A, and Criminal Procedure Code (V of 1898). The sent email was related to the threatening messages of death and kidnapping. There was a clear record of registration of internet connection and email account with the name of co-accused. The motive of creating a threat was not personal but the federal government under the influence of foreign government agenda to spread fear and insecurity in public. Another critical case of terrorism, kidnapping and murder of a foreign journalist (2020 SCMR 2096) was also filed and resolved under the same Anti-Terrorism Act (XXVII of 1997). The admissibility of record of the source of email sent through a specific internet connection and emails cluster proved helpful in tracing the accused verified by the technical forensic department. Resultantly, the police found the related technological devices associated with communicating with the deceased. These devices were the laptop, scanner, polaroid, and zoom cameras used to connect with the deceased and family to build strong connections. After revealing of truth, the accused and co-accused were arrested, and the court sentenced them to be imprisoned throughout life. The case of custody (2020 CLC 1029) demonstrated the evidence that emails and digital communication were considered authentic after verifying their privacy, encryption and digital signature.

\section{Cell phones}

The cell phone is a portable electronic device for long-range communication in personal. Additionally, along with the standard voice functioning as a telephone, cell phone offers extra services including text message, SMS, email, access to the internet, MMS and making and receiving photographs and videos from a similar source. The smart cells are connected to the cellular network of the base stations, which is connected to the Public Switch Telephone Network (PSTN) as the expression of being satellite cell phones. Due to the easy accessibility and high penetration of cell 
phones, they are inexorably connected to enhancing criminal activities. The availability of ample storage space in modern phones makes them useful to store data for any theft purpose and theft learning. There is a system of recording and saving SMS and phone calls that could be used positively or negatively. The insertion of a removable memory card (SD card) also saved the person's information to trace.

Furthermore, the details of GPS and Calendar also proved helpful as evidence to track the activities of the accused or victim. The recorded case 2007 PCRLJ 1876 also reflects this statement that found the accused punished for recording the videos and the SMS conversation with the victim to torcher and theft in the house. Another case reference \# 2021 SCMR 404, found the accused cell phone the place of the crime scene. It helped to arrest the accused. In case 2021 PLD 600, the accused was arrested by tracing the cell phone record and charged for murder and theft.

\section{Computer-related data}

Computers are being used to fight crimes as digital evidence in law enforcement agencies. Digital information refers to the information stored and transferred in binary form that the courts can trust. While using the computer, the evidence could be generated by saving data in hard drives, floppy disks, USB drives, external hard or CDs. In comparison, they were using the internet, emails, and internet usage record in the history of the browse also helpful to identify the criminal's activities. In 2005, the floppy disk helped the investigators to approach a serial killer who thwarted police capture and murdered at least ten victims. In order to fight the e-crimes, modern evidence is collected by the admissibility of digital proofs known as computer forensics. Law enforcement agencies are needed to train their officers to deal with rapidly evolving technologies such as computer operating systems (UNODC, 2015).

In Pakistan, several cases have been resolved by using the computer as an evidential representation. In the case of 2021 SCRM 873, the police and investigation officers found using a computer to threaten the victim via emails. The victim was kidnapped after receiving threatening emails for a long time. The investigation officers also received a copy of video clips that were reexamined to check the authenticity of the provided information. After the police inquiry and remand, the co-accused admitted the crime under police torture and resolved the case. In another case of sexual offense 2021 YLR 1291, the prosecution's case got strength by the recovery of computer, CPU, SD card and USB drive along with cell phone. The digital Forensic Examination Report strengthened the report by confirming no editing, no frame insertion and deleting the original data.

\section{Audio recordings}

Concerning the case hearing, 2019 PLD 675, according to article 164 of Punjab Forensic Science Agency Act (XIII of 2007), audiotape or video recording providing the admissibility of evidence require verification and testing technological forensics to check the authenticity before presenting in front of the court of law.

The audio recording is presented as modern evidence while sending or receiving the voice recording through social media platforms or saving the phone call recordings. In an audio recording, the use of a tape recorder was also found useful to present the voice originality of the accused or victim. In the history of resolved cases of Pakistan, a case 2020 PLC(CS) 890 of misconducting, bribe and corruption, the investigation officers found the originality of the recorded voice of accused with the verification of several persons knew the accused. There was no fake voiceover and voice makeup that was also admitted by the accused after further inquiry. The majority of the penalty was imposed on the accused and then the case was dismissed. While in some other cases, 2021 SCRM 522 and 2021 YLR 728, the investigation did not prove the recording as the authentic source of evidence after reexamination. There was no evidence of transcription of calls even after having Call Detail Record (CDR). So, the accused were released by considering the audio recording as weak proof against them.

\section{Photographs and screenshots}

In the Pakistani judiciary system, the acceptability of photographs and screenshots as modern evidence is considered documentary evidence that needs to send to the high courts (Rules and the Order of High Court Lahore, Volume III). The presentation of evidence after examination by Ballistic expert, the Director (Forensic Science Laboratory Punjab) is represented with the genuine reasons and conclusion that how and why he arrived at this conclusion and its purpose. This all inquiry happened before the committee magistrate sees and concerned the photographs and all other cartridges. The copies of the pictures generated by the Ballistic expert are placed on the record inspected by the defense councils. A case (Criminal appeals No. 120-122, 2019) related to pictorial evidence has been resolved by the Pakistani court in which a female was blamed for being involved in the crime. The inquiry committee prepared a report in collaboration with the Forensic Analysis report under the Cyber Crime Forensic 
Laboratory of Islamabad that proved the victim innocent. These pictures were found in the cellphone of the accused, who was the neighbor of the victim.

\section{Videos, films and video cassettes}

According to the forensic report, the video clip with no reliance and genuineness cannot be held as evidence that happened in a resolved case of Pakistani court (2016 SCRM 2084). The guidance of providing the video or audio clips in the courts is demonstrated in the case of Ishfaq Ahmed Mirza with the Federation of Pakistan (2019 PLD SC 675). The following guidelines were followed to present video films and audio recording in the court that:

1. The video or audiotape can only be relied upon in court in presented and proved genuine, not tampered or doctored,

2. The forensic report is admissible when prepared by the analysis of Punjab Forensic Science Agency, Act 2007 ,

3. Under article 164 of Qanun-e-Shahadat, 1984, it is the courts' discretion to allow and accept the evidence available in the form of audio or video recording (CLR.AS.599-602/2020).

4. The tape should be present following the law of evidence even it is allowed to produce as evidence in court hearings.

5. The accuracy of the recording and videotapes must be proved as satisfactory evidence, circumstantial or direct to rule out any type of tampering possibility with the evidence.

6. The audio or video recording must be present as evidence when recording the actuality of conversation and the event while taking place.

7. The person recording the video should be present while presenting the evidence in the court himself.

8. The tape should be paly in the court in front of the accused and victim.

9. It should be clear in the voice and recognition of the individuals in the video recording.

10. The person recording the video must recognize the voice, face and person speaking in the video.

11. The person must disclose the recording date while presenting in the court, and the confidentiality of the tape must be promised before producing in the courts.

12. The audio or videotape presentation at the judiciary procedure's last stage may be taken as suspicious.

13. The person needs to fill the formal application before the court who desires to represent the video clip, audio recording, or video cassette in the court as evidence.

Considering the abovementioned clauses, a murder case (Criminal Appeals No. 599-602, 2020; Criminal petition No. 1085-86, 2020) has been a video cassette was received as evidence and reviewed by the court. Another case (2021 YLR 1291) was also solved related to the sexual offense, sodomy, obscene acts, rape and criminal intimidation under Ss. 375-77, $294 \& 506$. The accused was arrested by the admissibility of the provided evidence of video recordings in the criminal's cell phone, memory card, USB and computer. No clue was found of the fraud and duplication of the videos, while multiple porn and sexually abusive videos were found. The accused was sentenced to imprisonment for life.

\section{CCTV footage}

Closed Circuit Television (CCTV) camera is used for security purposes to avoid any theft, robbery and criminal activities at the place of insertion. In Pakistan, it was suggested by the additional IG Karachi to admit the CCTV footage as a sort of evidence because it helps in identifying and capturing the criminals. In this way, the crime ratio could be lower down. The case hearing in the federal court (2016 SCMR 2084) discussed CCTV as an insufficient source of evidence to rely on unless it proves genuine. It would be accepted as genuine if verified and examined the person who prepared the footage from the CCTV system. Another case (Appeal No. 878(R)CS/2019) also demonstrated the CCTV footage as authentic evidence until the technological forensics of Pakistan examines it. The attachment of the legal report with the footage can be used as verified and authentic evidence in dealing with the cases.

\section{Polygraphy test}

The polygraph test is a technique to investigate the truth that is commonly known as a lie detector. It considers calculating the body changing including pulse rate, heartbeat, blood pressure, skin contraction and respiration during asking the questions and answering. In western countries, this technique is commonly used by private detectives frequently. The polygraph test is not reliable if conducted by an unskillful and untrained person. Some private business firms are using this device to disclose wrongful acts in criminal activities. The Federal Board of Investigation uses 
this equipment to connect the criminal and civil nature of cases. The polygraph test is used successfully to explore the lie and veracity of two persons' statements at the same issue at different times. In legal terms, it is known as pair testing. It is important to note that any interference during the test can disturb the graphic display and variation occurring while investigating. In 2016, a case 1:15-cv-00824-RMC was resolved by using the polygraph technique. A Pakistan-born man Mr. Gill committed the crime against the FBI and was included in some cyber and corruption crimes. He admitted the crime and was punished accordingly (Collyer, 2016).

In Pakistan, a resolved case 2018 PCRLJN 45 tested the accused with a polygraph test. It was found that the accused was not guilty and falsely involved in the case. So, the court resolved the case by accepting his pre-arrest bail. Another case, 2019 SCMR 1914, also helped prove the accused innocent in the murder case of two children. After the statement verification by the two persons, the results were unexplained that did not prove the accused guilty. So, the bail was allowed under the circumstances. The latest use of polygraphy test was applied on Zahir Jaffer in Noor Muqaddam murder case 2021.

\section{DNA test}

In DNA tests, the human blood and hair sample evidence is accepted with cautions and forensic examination. There is the need for chemical examination and the reference of the evidence, how, why and from where taken. The Pakistan government has appointed a serologist to verify and distinguish the human blood from the others', carried out in Islamabad for medico-legal work of discriminating the human blood from the other blood.

Moreover, in Pakistan, DNA tests are conducted to resolve two types of verification: paternity/legitimacy and sexual offenders (Chemma, 2016). The recent literature also found that the issue also raised in DNA test validity while delaying the medical examination, improper dealing with the evidentiary material and collection of samples and compromising the probative biological evidence. However, the lack of proper information of DNA test results validation by the lawmakers, lawyers, judicial officers and inadequate existing laws to properly channel DNA evidence also influence the admissibility of evidence in criminal trials (Ahmad, 2018). The reported case (2021 SCRM 799) showed a two-year child's doubtful maternal custody and kidnapping. The court ordered to conduct DNA testing to find if the child was the mother's biological child.

Moreover, the court also found in DNA testing that the mother used the substances and traded them. After arresting the lady, the court proceeded with the case hearing until all facts and evidence proved her guilt. A case (2021 PLD 362) of rape and murder of an innocent child was also resolved by the DNA testing of the deceased and accused and left no margin of doubts after medical testing and DNA reports. The sentences and convictions were awarded to the accused along with the death sentences. The unnatural offense, murder, and sexual abuses under the Punjab Forensic Science Agency Act (XIII of 2007) and Qanun-e-Shahadat (10 of 1984) were resolved by the admissibility of DNA evidence and medical reports.

\section{Conclusion}

The study concludes that the use of modern devices as evidence representation seemed and proved useful in judiciary procedures after the amendments in the articles of Qanun-e-Shahadat order 1984 and Electronic Certification Accreditation Council under Section 18. Several cases have been resolved by evidence from modern technological modes that could be difficult to resolve without modern devices. However, there is the need to work on some laws establishment the implication of modern devices as evidence to control cybercrimes. Lawmakers, lawyers, and other forensic and judiciary officers must be trained to find the evidence's authenticity and validity with modern techniques. After using the evidence to resolve the case, it should be handled and destroyed carefully to avoid its misuse and misconduct at any other place. Furthermore, the accessibility and validity of modern devices need to be sure for all classes of people to lower down the crime ratio in Pakistan.

\section{References}

Abbasi, H., \& Iqbal, M. A. (2020). Authentication of Electronic Evidence; A Journey from Electronic Discovery to Digital Forensic Experts in Western Law-Recommendations for Pakistan. Journal of Social Sciences \& Humanities (1994-7046), 28(1). 
Abbasi, H., Rafique, S., \& Badshah, S. N. (2021). Critical Analysis of Pakistani law of Electronic Evidence from the Perspective of Sharī'ah and English Law-Recommendations for Pakistan. Tahdhib-al-Afkar, 33-50.

Ahmad, A. A. A. (2018). DNA Fingerprints Facial Prints and Other Digital Forensics as Evidence in Criminal Investigation and Court Proceedings. IJECI, 2(1), 9-9.

Cheema, S. A. (2016). DNA Evidence in Pakistani Courts: An Analysis. LUMS LJ, 3, 1.

Collyer, R. M. (2016). Gill v. DOJ. Collections, 2016, 07-22.

Gabriel, H. D. (2000). The new United States uniform electronic transactions act: substantive provisions, drafting history and comparison to the UNCITRAL model law on electronic commerce. Uniform Law Review-Revue de droit uniforme, 5(4), 651-664.

Series, D. Criminal Justice Handbook Series The Criminal Justice Handbook Series is a series of tools developed by the United Nations Office on Drugs and Crime (UNODC) to support countries in implementing the rule of law and the development of crime prevention and criminal justice reform. It can be used in a variety of contexts, including as part of UNODC technical assistance and capacity-building projects, both as a reference document and as a training tool. English Also available in: Spanish, French.

Singleton, S. (March 17, 1999). Privacy Issues In Federal Systems: A Constitutional Perspective. Speech to National Institute of Standards and Technology Computer System Security and Privacy Advisory Board Meeting. Cato Institute.

Usman, M. (2017). Cyber Crime: Pakistani Perspective. Islamabad Law Review, 1(03), 18-40.

Zakar, R., Zakar, M. Z., Qureshi, S., \& Fischer, F. (2014). Harnessing information technology to improve women's health information: evidence from Pakistan. BMC women's health, 14(1), 1-13. 